\title{
ビル用エネルギー供給システムの最適更新計画* (問題構成と経済性分析)
}

\author{
吉田修*1, 伊東弘一*2, 横山良平*2
Optimal Renewal Planning of Energy Supply Systems for Buildings (Problem Formulation and Economic Analysis)

\author{
Shu YOSHIDA*3, Koichi ITO and Ryohei YOKOYAMA \\ ${ }^{* 3}$ Research and Development Center, Kansai Electric Power Co., Inc., \\ 3-11-20 Nakoji, Amagasaki-shi, Hyogo, 661-0974 Japan
}

\begin{abstract}
An optimization method has been proposed for the renewal planning of energy supply systems installed into buildings. Assuming the raise of future equipment's energy efficiency, the renewal year is determined optimally together with the structure of renewal system. In the mathematical optimization formulation, the average value of the annual total cost of the system during the evaluation period is minimized in consideration of system's operational strategy corresponding to seasonal and hourly energy demands requirement. Through the numerical study for an office building, it is shown that $2 \sim 3 \%$ reduction of the average value of the annual total cost coulde be achieved if the renewal planning could be optimized based on the proposed method. The influence of the following items on the renewal solution is also clarified; i.e., available types of equipment to be installed newly, upgrading rates of performance, and so on. For example, it is recognized that the optimal renewal year becomes later if the future upgrading rate of equipment's performace is assumed to be high enough.
\end{abstract}

Key Words: Energy Saving, Systems Engineering, Optimal Design, Energy Supply Planning, Renewal, Economic Analysis

\section{1. 緒言}

我が国の事務所・ホテル・病院などの各種ビルは, 近年約 60 年前後と長寿命化が計られてきている。一 方で,これらのビルが必要とする冷暖房や給湯などの エネルギーを供給するシステムの寿命は高々 15 20 年 程度にすぎない. したがって，新築ビルに対するシス テム導入の計画よりも，システムの更新計画の割合が 多く発生することとなる.

上述のエネルギー供給システムの更新においては, すべての機器が撤去されて新しいシステムに置換さ れることはほとんど無く, 省エネルギー化を促進し て行く新しいビジネス手法として注目を集めている ESCO(Energy Service Company) 事業に例示されるよ うに, 一部の機器が適当に更新される場合が一般的で ある。

$$
\text { 上記システムの更新計画においては, 既存システム }
$$

* 原稿受付 2005 年 12 月 19 日.

*1 正員, 関西電力 (株) 研究開発室エネルギー利用技術研究所 （画 661-0974 尼崎市若王子 3-11-20）。

*2 正員, 大阪府立大学大学院工学研究科(愚599-8531 堺市学 園町 1-1)。

E-mail : yoshida@ese.me.osakafu-u.ac.jp
の今後の機器劣化を含めた性能特性, メンテナンス費, 更新時の撤去機器下取り価格, 今後の各種技術進歩を 反映した新型高効率機器の性能特性および価格, 更新 時の工事費，年間に渡るエネルギー需要量および更新 システムの運用方策，入力エネルギー料金体系，金利 を含む経済因子など，様々な要因を総合的に考慮して 計画立案を行っていく必要がある.

従来, このような更新計画問題の立案に対して, シ ステム設計者らは自らの過去の経験と勘に基づいて試 行錯誤的にいくつかの代替案を比較検討し, 適当にシ ステム更新時期と既設撤去機器および新規導入機器類 を決定してきたのが現状である，その理由は，新設シ

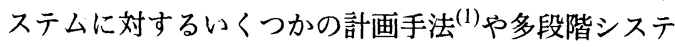
厶拡張計画問題に対する研究 ${ }^{(2)}$ はなされているものの, システムの更新計画に対する合理性に富む方法論に関 する研究が皆無といえる程過去なされてこなかつたこ とに起因するものと思われる。 また，新設システムの 計画よりも更新計画の問題がより多様な各種要因を総 合的に考慮する必要があるため, より複雑な計画問題 の構成となり, 求解もより困難性を伴っている。 しか しながら，ESCO 事業に代表されるように，システム 


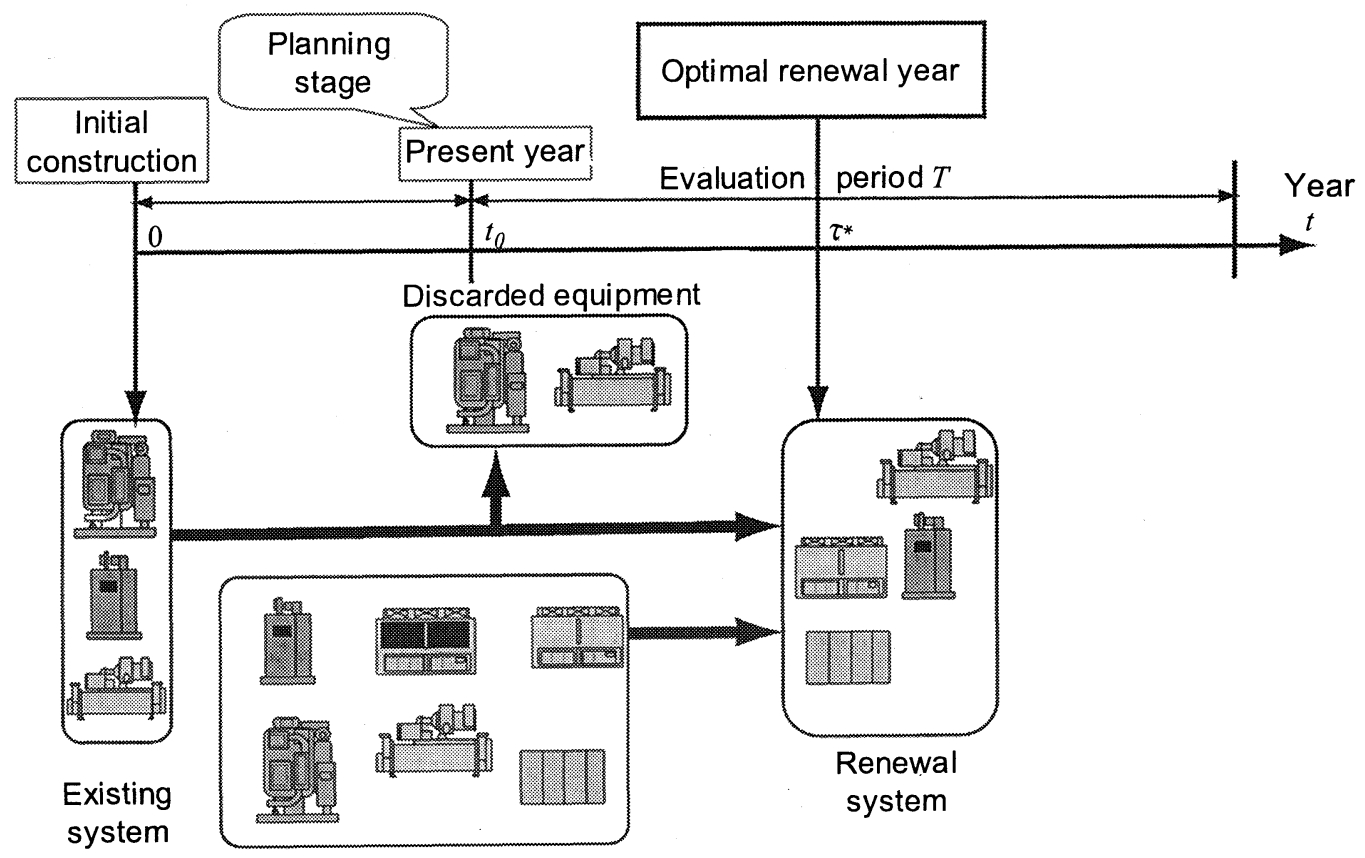

Alternative equipment installed newly

Fig. 1 Structure of optimal renewal planning

更新による省エネルギー化の促進は社会的にも切望さ れている課題であり, また更新計画問題がより複雑で あればある程, より合理的方法論の探索が必要とされ ているものと考えられる。

本研究では, 以上述べてきた視点より, 一つのシス テム計画手法として最適化手法に基づくエネルギー供 給システム更新計画のための方法論的検討を行ったも のである.ここで, 最適化手法を導入した理由は, そ れが, 勘に基づく試行錯誤的方法論よりもより合理性 に富むシンセンス手法と考えられるからである，以下 では，まず最適更新計画問題の概要と解法について述 べる.また, 標準的ビルに対する数值計算を通じて, 新規導入可能な機器機種や, 今後の性能向上の相異に よる影響について分析を行う。

\section{2. 最適更新計画問題}

\section{$2 \cdot 1$ 問題構成の概要 図 1 は, 本研究で考察し} たビル用エネルギー供給システムの最適更新計画問題 の構成の概要を示したものである. 年の経過を表す変 数を $t$ とし, $t=0$ で導入された既存システムの更新計 画を, 現時点 $t=t_{0}$ で行うものとする. 更新は, シス テムの評価期間 $t=t_{0} \sim t_{0}+T$ (すなわち $T$ は評価期 間の長さ）の間の $t=\tau$ 年で一回のみ実施されるもの
とする.ただし，図中で $\tau=\tau^{*}$ は最も望ましいと判断 された最適更新年を表した值であり，この $\tau^{*}$ は以下に 述べる最適化手法により決定される未知変数である. システムの更新に関しては, 既存システムの効率の低 いまたは不経済で不要な機器を撤去し, さらに図中に 示す新規導入可能な代替機器群の中から選定され, 更 新システムが構成される。ここで, 撤去機器, および 新規導入機器の機種ならびに機器容量は最適化手法に より決定される未知変数である。新規導入機器の同一 機種の台数は, 方法論的には複数台としても問題構成 が可能ではあるが，本報においては簡単に一台のみと 仮定する。なお, 既存および新規導入機器は, 評価期 間内においてその寿命に達しないものと仮定する.

2.2 システム経済性評価 次にシステム評価に 関しては, 経済性のみを考虑する。すなわち, 省エネ ルギー性や環境性を考慮した多目的最適化に関しては 今後の課題とする. 図 2 は, システムの経済性検討に おける諸経費の発生を示したものである。 まず, シス テム新設時 $(t=0)$ および更新時 $(t=\tau)$ においてそ れぞれ新設設備費および設備更新費が発生する。 さら に，図 2 に示すように毎年の運用費としての入力エネ ルギー費およびメンテナンス費が発生する. その他の 


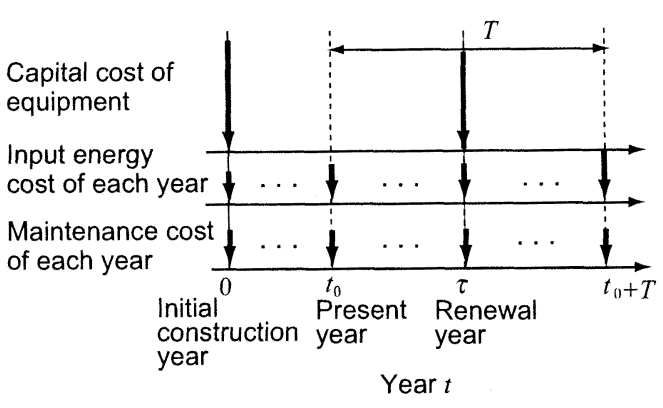

Fig. 2 Economic evaluation of renewal system

経費としては人件費などが発生するが，ここではシス テムの更新代替案に関連せず一定として経済性評価の 経済項目から除くものと仮定する.

以上の経費項目の経済性分析を，本手法においては 基本的に年価法に基づいて行うものとする，すなわち， 各機器の耐用年数をここでは単純に機種によらず一定 （方法論的には機種に依存させることも可能）で $\kappa$ 年 とし, 金利を $i \% /$ 年, 耐用年数後の残存価值率を $\varepsilon$ と仮定する。また，更新における既存機器撤去時の売 却費は，その残存価值に下取り評価率 $w$ を乗じた值と する，さらに，新规導入機器の設備費は，ここでは単 純に機器容量に比例するものとする。 また, 機器導入 に関連した工事費は機器設備費に工事費用率 $\beta$ を乗じ て算出する. 次に, 年間の入力エネルギー費について は，電力およびガスなどの料金体系を反映した定額基 本料金，流量基本料金，および従量料金に基づいて計 算する。この際，年間に渡って変動する各時刻のエネ ルギー需要量に対して，入力エネルギー費をシステム 運用方策の関数として考慮する(3)(4). また, 年間のメ ンテナンス費に関しては, 各機器の容量に機種により 異なる値の比例係数を乗じて算出する。これらのシス テム更新時の機器設備および工事費を含めた年間設備 費，年間入力エネルギー費および年間メンテナンス費 の合計である年間総経費を評価期間 $T$ の各年について それぞれ現在価值に換算する。これらの各年に対して 異なる年間総経費の評価期間 $T$ 内における平均值を 本計画問題における最小化すべき目的関数として採用 する.

2.3 その他の前提条件 年間に渡るエネルギー 需要量に関しては, システム検討期間内において変化 しないものと仮定する. 更新に際し新規導入可能な各 種代替機器の効率は, 新設時から機種毎に毎年一定率 $\alpha_{j}$ (ただし $j$ は機器機種を表す) で向上するものと仮
定する，ただし，方法論的には機器効率向上が一定で なくてもよい，既存および導入機器の劣化に関しては, システムの評価期間内において新設時および更新時に エネルギー需要の各種種類に対するシステムとしての 供給余裕率が無い場合, 供給不足を生じる事態となる. 方法論的には, 機器劣化率を機種毎に導入して定式化 が可能である，本報においては，他の各種要因が更新 計画に及ぼす影響をまず分析する目的を優先し，劣化 が無いものとし, システム供給余裕率は零と仮定した.

各機器の部分負荷に対する性能特性に関しては一次 式で近似することも可能であるが，最適解導出に長時 間を要するため,ここでは単純に線形近似した。なお， 本計画問題の詳細な定式化に関しては紙面の制約上省 略する.

2.4 解法 以上述べてきた最適更新計画問題は, 混合整数線形計画問題として定式化できる。ここで, 未知変数として 0-1 整数変数が必要となるのは, 既 存システムの各機器存続・撤去および新規導入機器と しての採用・非採用を定式化する必要が生じるためで ある。

本最避化問題における最小化すべき目的関数は前述 したようにシステムの年間総経費の平均值であり，未 知変数は既存システム撤去機器, 新規導入機器機種お よびその機器容量, 各種エネルギー需要量に対するシ ステム運用方策，最適更新年 $\tau^{*}$ である.

制約条件としては, 各機器性能特性, 各種エネル ギ一需給条件, 新規導入可能な機器の容量上・下限制 約である。

本問題に対する数值計算法としては，分枝限定法と シンプレックス法を組み合わせた GAMS/CPLEX ${ }^{(5)}$ 採用した。なお，システムの新設時に対する最適計画 問題と異なり, 更新計画問題においては, 各種機器の 将来に渡る性能特性向上を考慮する必要上，評価期間 の各年においてシステムの運用方策および運用費な ぞが変化するため, 解の導出がより難しくなる特徴が ある。

\section{3. 事務所ビルに対する数値分析}

3.1 前提条件本報では，2 章で提案した最適 更新計画の問題構成の妥当性を検証するために, 延床 面積が約 $15000 \mathrm{~m}^{2}$ の標準的事務所ビルを対象として 数值分析を行った。 その基礎となるエネルギー需要量 の想定を文献 ${ }^{(6)}$ に基づいて行った。

まず，対象ビルの年間に渡るエネルギー需要量に関 しては, 各季節 (夏·冬・中間期) の 3 代表日に夏期・ 冬期の 2 最大需要日を加えた 5 代表日における 1 時間 
Table 1 Economic and performance charactristic values of existing equipment

\begin{tabular}{l|c|c|c|l}
\hline \multicolumn{1}{c|}{ Equipment } & Capital unit cost & $\begin{array}{c}\text { Maintenance } \\
\text { unit cost }\end{array}$ & Capacity & Performance characteristic value \\
\hline $\begin{array}{l}\text { Electric compression } \\
\text { refrigerator }\end{array}$ & $12600 \mathrm{yen} / \mathrm{kW}+10.626 \times 10^{6} \mathrm{yen}$ & $597 \mathrm{yen} /(\mathrm{kW} \cdot \mathrm{y})$ & $1041 \mathrm{~kW}$ & $\mathrm{COP}^{*}$ (space cooling) \\
\hline $\begin{array}{l}\text { Steam boiler } \\
\begin{array}{l}\text { Gas-fired absorption } \\
\text { refrigerator }\end{array}\end{array}$ & $3720 \mathrm{yen} / \mathrm{kW}+0.591 \times 10^{6} \mathrm{yen}$ & - & $113 \mathrm{~kW}$ & Thermal efficiency (space heating) 0.89 \\
\hline
\end{tabular}

${ }^{*} \mathrm{COP}=$ Coefficient of performance

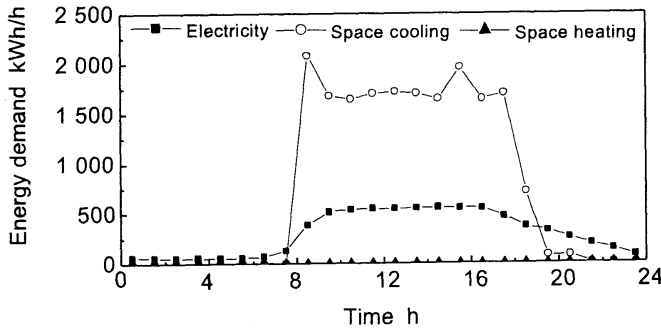

(a) Summer peak

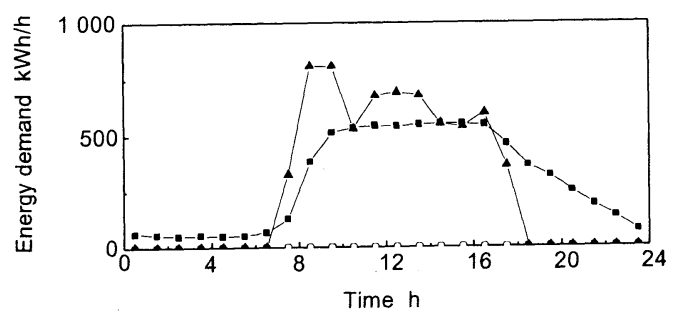

(b) Winter peak

Fig. 3 Example of hourly energy demands

毎のデータを採用した。その一例として図 3 に夏期・ 冬期最大需要日の電力・冷暖房需要量を示す。なお, 年間に渡る電力・冷房・暖房需要の最大值はそれぞれ $555,2083,691 \mathrm{kWh} / \mathrm{h}$ である。

既存システムは図 4 の上部に示すターボ冷凍機 (RE), 蒸気ボイラ (BS) およびガス吸収式冷温水器 (RG) 各 1 台より構成され, 電力は買電により供給されるものと する.なお，これらの機器類の新設時の設備費, メン テナン費単価, 容量（RG は冷房能力で表示）および 新設時の効率を表 1 に示しておく.ただし，BSのメ ンテナンス費は無視した. 新規導入可能な機器機種と しては, 図4の下部に示すように, 既存機種の RE,BS および RGに加えて電動ヒートポンプ (HP), ブライン ヒートポンプ $(\mathrm{HB})$ とそれに付随したブライン熱交換 器 (HEB) および温水・氷蓄熱槽 (IHB) を考慮する ${ }^{(7)}$. ここで, HP は新設時のシステムに採用されなかった

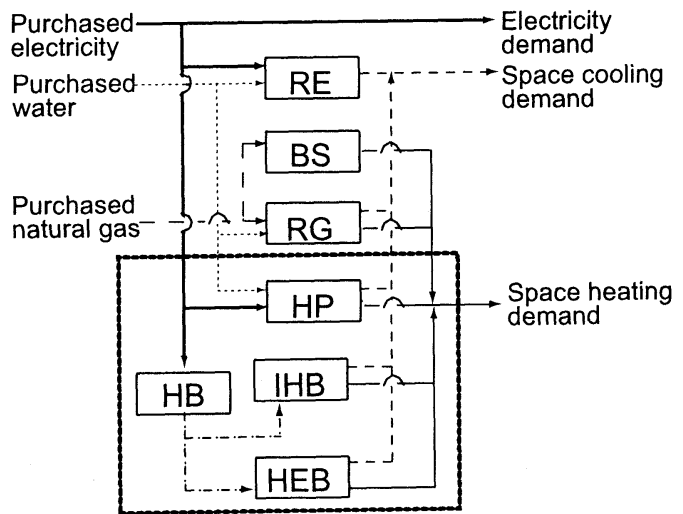

New type of alternative equipment to be installed

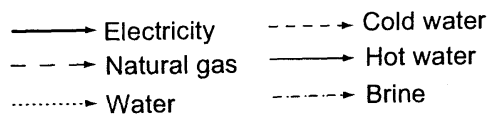

Fig. 4 Structure of renewal system

が, 当時導入可能な機器機種であった。一方, HB は ここ数年前に開発された新型機器機種である。なお, HEB および IHB の機器容量は HB に比例的に決定さ れるものとし，またそれらの機器設備費はHBにすべ て含めて考慮した. また, 表 2 に新規導入可能な各機 器の設備費, メンテナンス費単価, 最小機器容量およ び現時点における効率を示す.なお, 最大機器容量に 関しては複数台の機器導入を想定してここでは制約を 設けない. また, RG,HP および HB の冷房と暖房を共 に出力可能な機器の容量に関しては, 冷房供給能力に 基づいて表す。

次に, システムの更新に関して, 表 3 に示す各種前 提条件を設定した。 すなわち, システムの新設時から $t_{0}=7$ 年後の時点で更新計画の検討を行うものとし, 評 価期間の長さを $T=15$ 年とする. また, 既設および 新規導入各機器の耐用年数を, ここでは単純にすべて 同一に $\kappa=22$ 年と仮定する. システムの経済性評価 
Table 2 Economic and performance characteristic values of equipment installed newly

\begin{tabular}{|c|c|c|c|c|c|c|}
\hline \multirow[t]{2}{*}{ Equipment } & \multirow[t]{2}{*}{ Capital unit cost } & \multirow{2}{*}{$\begin{array}{l}\text { Maintenance } \\
\text { unit cost }\end{array}$} & \multicolumn{2}{|c|}{$\begin{array}{c}\text { Range } \\
\text { of capacity } \\
\end{array}$} & \multirow{2}{*}{\multicolumn{2}{|c|}{$\begin{array}{c}\text { Performance } \\
\text { characteristic value }\end{array}$}} \\
\hline & & & Min & $\operatorname{Max}$ & & \\
\hline $\begin{array}{l}\text { Electric compression } \\
\text { refrigerator }\end{array}$ & 12600 yen $/ \mathrm{kW}+10.626 \times 10^{6}$ yen & $597 \mathrm{yen} /(\mathrm{kW} \cdot \mathrm{y})$ & $352 \mathrm{~kW}$ & - & $\mathrm{COP}^{*}$ (space cooling) & 5.5 \\
\hline Steam boiler & 3720 yen $/ \mathrm{kW}+0.591 \times 10^{6}$ yen & 706 yen $/(\mathrm{kW} \cdot \mathrm{y})$ & $125 \mathrm{~kW}$ & - & Thermal efficiency (space heating) & 0.9 \\
\hline $\begin{array}{l}\text { Gas-fired absorption } \\
\text { refrigerator }\end{array}$ & 11400 yen $/ \mathrm{kW}+7.11 \times 10^{6}$ yen & 995 yen $/(\mathrm{kW} \cdot \mathrm{y})$ & $352 \mathrm{~kW}$ & - & $\begin{array}{l}\operatorname{COP}^{*} \text { (space cooling) } \\
\text { Thermal efficiency (space heating) }\end{array}$ & $\begin{array}{l}1.1 \\
0.9 \\
\end{array}$ \\
\hline Electric heat pump & 44700 yen $/ \mathrm{kW}+0.35 \times 10^{6}$ yen & 110 yen $/(\mathrm{kW} \cdot \mathrm{y})$ & $118 \mathrm{~kW}$ & 一 & $\begin{array}{l}\mathrm{COP}^{*} \text { (space cooling) } \\
\text { Thermal efficiency (space heating) }\end{array}$ & $\begin{array}{l}3.1 \\
2.7\end{array}$ \\
\hline $\begin{array}{l}\text { Brine electric heat } \\
\text { pump system }\end{array}$ & 67300 yen $/ \mathrm{kW}+3.7 \times 10^{6}$ yen & 894 yen $/(\mathrm{kW} \cdot \mathrm{y})$ & $118 \mathrm{~kW}$ & - & $\begin{array}{l}\text { Thermal efficiency (space heating) } \\
\text { COP }^{*} \text { (space cooling) } \\
\text { Thermal efficiency (brine) } \\
\text { COP }^{*} \text { (brine) }\end{array}$ & $\begin{array}{l}3.1 \\
2.7 \\
3.0 \\
2.0 \\
\end{array}$ \\
\hline
\end{tabular}

${ }^{*} \mathrm{COP}=$ Coefficient of performance

Table 3 Values of miscellaneous parameters

\begin{tabular}{l|c|c}
\hline \multicolumn{1}{c|}{ Item } & Symbol & Value \\
\hline Present year & $t_{0}$ & $7 \mathrm{y}$ \\
\hline Evaluation period & $T$ & $15 \mathrm{y}$ \\
\hline Life of equipment & $\kappa$ & $22 \mathrm{y}$ \\
\hline Interest rate & $i$ & $3 \% / \mathrm{y}$ \\
\hline Trade-in value rate & $w$ & 0.5 \\
\hline Salvage value rate & $\varepsilon$ & 0 \\
\hline Construction cost rate & $\beta$ & 0.2 \\
\hline
\end{tabular}

に関連して，金利 $i=3 \% /$ 年，機器の下取り評価率 $w=0.5$, 残存価値率 $\varepsilon=0$ および更新時新規導入機器 工事費用率 $\beta=0.2$ とする.

以下の数値分析においては, 更新時に表 3 に示す機 器機種がすべて導入可能とした場合 (ケース A) と, HB および HEB と IHB が導入可能でない場合 (ケース B) の比較分析も行うこととした。

次に，入力エネルギーとしての電力およびガスの料 金体系を表 4 に示す。なお， RE，RGおよびHPには 上水が必要となるため，その単価を表 4 に示す.

新規導入可能機器類の年間性能向上率 $\alpha_{j}$ に関して は，過去の技術進歩の動向をデー夕収集・分析し，表 5

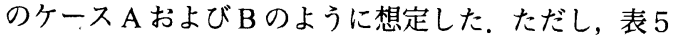
の $\alpha_{j}$ は年度毎に複利的に変化するのではなく, 現時点 を基準として等差的に効率が向上するものとした。さ らに, 技術進歩による機器機種性能向上が更新計画に 与える影響を分析するために，ケースAに対して機器 毎に技術進歩を変化させた以下の 3 つのケース（A-1 〜A-3）を想定して追加検討した.これらのケースでは,
これまでの実績的な技術進歩の割合（ケースA）より

も，今後の性能向上が低くなるものと仮定した。

-ケースA-1:性能向上が少し低い場合

-ケース A-2:性能向上が低い場合

-ケース A-3:性能向上がほとんど見込めない場合

3.2 最適更新解 $3 \cdot 1$ 節で述べた前提条件の下 に，2・4節の手法に基づき最適解を導出した. 図 5 に, ケース A, Bにおけるそれぞれの最適更新年 $\tau^{*}=10$ お よび 12 年に対する年間総経費削減率を示した。なお, 参考までに, 更新年 $\tau$ を変化させた場合の削減率を同 時に図示した。ここで削減率は, 更新を将来全く行わ ない場合の評価期間 $T$ 内における年間総経費をそれぞ れ現在価値に換算した値の平均值を基準としている.

また, 図 6 はケース $\mathrm{A}$, 最適更新年 $\tau^{*}=10$ 年にお ける夏期日に対するシステムの最適運用方策を示した ものである.

表 6 は, 図 5 に示す更新解における撤去機器ならび に新規導入機器の機種と最適機器容量を示している.

図 7 には,ケース A およびA-1〜A-3 に対する年間 総経費削減率の $\tau$ に対する変化を示した。なお, 図 8 は, 図 7 の各ケースに対する検討期間中の撤去機器お よび新規導入機器機種を更新年 $\tau$ に対して示したもの である。

なお，1つのケースに対する最適解の導出に必要 な計算時間は, ワークステーション HP Aplha Station DS15 で約 30 40 分であった.

\section{$3 \cdot 3$ 結果に対する考察}


Table 4 Rates of purchased electricity, natural gas and water

\begin{tabular}{l|c|c|c}
\hline \multirow{2}{*}{ Utility } & \multicolumn{3}{|c}{ Unit cost } \\
\cline { 2 - 4 } & Customer charge & Demand charge & Energy charge \\
\hline Electricity & - & $1.66 \times 10^{3} \mathrm{yen} /(\mathrm{kW} \cdot \mathrm{month})$ & $\begin{array}{r}\text { (Summer) } 11.43 \text { yen } / \mathrm{kWh} \\
\text { (Middle, winter) } 10.39 \text { yen } / \mathrm{kWh}\end{array}$ \\
\hline $\begin{array}{l}\text { Electricity for } \\
\text { thermal storage }\end{array}$ & - & - & $(22: 00 \sim 8: 00) 4.28$ yen $/ \mathrm{kWh}$ \\
\hline Natural gas & $75 \times 10^{3}$ yen $/ \mathrm{month}$ & $\begin{array}{c}\text { (Summer, middle) } 0.928 \times 10^{3} \text { yen } /\left(\mathrm{month} \cdot \mathrm{m}^{3} / \mathrm{h}\right) \\
\text { (Winter) } 2.247 \times 10^{3} \text { yen } /\left(\mathrm{month} \cdot \mathrm{m}^{3} / \mathrm{h}\right)\end{array}$ & $\begin{array}{r}\left(\text { Summer, middle) } 28.19 \mathrm{yen} / \mathrm{m}^{3}\right. \\
(\text { Winter }) 32.10 \text { yen } / \mathrm{m}^{3}\end{array}$ \\
\hline Water & - & - & 550 yen $/ \mathrm{m}^{3}$ \\
\hline
\end{tabular}

Table 5 Upgrading rate of performance of equipment

\begin{tabular}{|c|c|c|c|c|c|c|}
\hline \multirow{2}{*}{\multicolumn{3}{|c|}{ Equipment }} & \multicolumn{4}{|c|}{$\alpha_{\mathrm{j}}$} \\
\hline & & & Cases A\&B & Case A-1 & Case A-2 & Case A-3 \\
\hline $\begin{array}{l}\text { Electric compression } \\
\text { refrigerator }\end{array}$ & $\alpha_{\mathrm{RE}}$ & Space cooling & $5 \% / y$ & $3 \% / y$ & $2 \% / y$ & $1 \% / y$ \\
\hline Steam boiler & $\alpha_{\mathrm{BS}}$ & Space heating & $0.2 \% / y$ & $0.2 \% / y$ & $0.2 \% / y$ & $0.2 \% / y$ \\
\hline $\begin{array}{l}\text { Gas-fired absorption } \\
\text { refrigerator }\end{array}$ & $\alpha_{\mathrm{RG}}$ & $\begin{array}{l}\text { Space cooling } \\
\text { Space heating }\end{array}$ & $\begin{array}{c}2 \% / y \\
0.2 \% / y \\
\end{array}$ & $\begin{array}{r}2 \% / y \\
0.2 \% / y \\
\end{array}$ & $\begin{array}{c}2 \% / y \\
0.2 \% / y \\
\end{array}$ & $\begin{array}{c}1 \% / y \\
0.2 \% / y\end{array}$ \\
\hline Electric heat pump & $\alpha_{\mathrm{HP}}$ & $\begin{array}{l}\text { Space cooling } \\
\text { Space heating }\end{array}$ & $\begin{array}{l}5 \% / y \\
5 \% / y \\
\end{array}$ & $\begin{array}{l}3 \% / y \\
3 \% / y \\
\end{array}$ & $\begin{array}{l}2 \% / y \\
2 \% / y \\
\end{array}$ & $\begin{array}{l}1 \% / y \\
1 \% / y \\
\end{array}$ \\
\hline $\begin{array}{l}\text { Brine electric heat } \\
\text { pump system }\end{array}$ & $\alpha_{\mathrm{HB}}$ & $\begin{array}{l}\text { Space cooling } \\
\text { Space heating }\end{array}$ & $\begin{array}{l}5 \% / y \\
5 \% / y \\
\end{array}$ & $\begin{array}{l}3 \% / y \\
3 \% / y \\
\end{array}$ & $\begin{array}{l}2 \% / y \\
2 \% / y\end{array}$ & $\begin{array}{l}1 \% / y \\
1 \% / y\end{array}$ \\
\hline
\end{tabular}

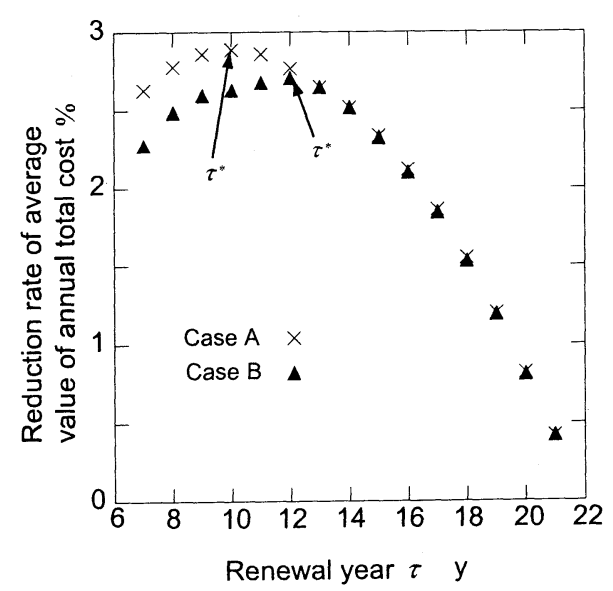

Fig. 5 Reduction rate of average value of annual total cost (influence of new type of equipment)

\section{3·3·1 新規導入可能な機器機種の影響 図 5 から,} ケース A および $\mathrm{B}$ の最適な更新年はそれぞれ $\tau^{*}=10$ 年および 12 年である.このときの更新によるシステ

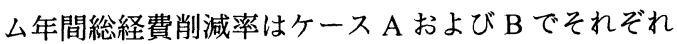
2.9 および 2.7\%である。このように，ケース B と比較 してケース A のように更新時に新規導入可能な機器 機種が多い程, 更新によりシステムの経済性向上が計 れることが明示されている、ケース A の最適更新年が ケース B に対して 2 年早まっているのは, HB という 高性能な新型機器が導入可能となった影響を反映した

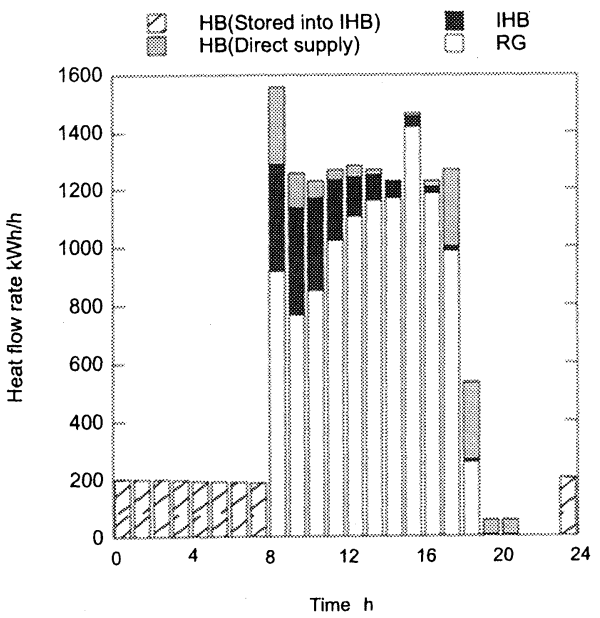

Fig. 6 Optimal operation of the system (case A, $\tau^{*}=$ $10 \mathrm{y}$, summer)

ものである．更新計画を行った現時点 $t_{0}$ が最適更新年 とならないのは，表 5 に示すように年経過とともに機 器性能の高い機器群の導入が可能となるためである. しかしながら, システムの評価期間が終了する間近に なつて更新を実行するのであれば，高性能な新規導入 機器の全評価期間における寄与率が低下するため, そ の効果は低減してしまう結果となる.

図 6 は,これらの最適更新計画案の計算過程におい て導出されたシステムの最適運用計画に関する結果 
の一例であるが, 安価な夜間電力を $\mathrm{HB}$ が適切に活用 して冷水を蓄熱し，昼間に上手く利用していることが 判る.

次に, 表 6 に示す結果に基づいて, 各ケースの更新 後のシステム機器構成について分析する。.まず, ケー ス A に関しては，相対的に性能が低い既存機器であ る RE およびRG を撤去する結果となっている。一方， BS に関しては新規導入可能機器の性能向上率が非常 に小さいため, 全更新年 $\tau$ に対して存続する結果と なっている. 新規導入機器については, 更新年が遅く なるに従って，まず RG および HBが導入され，次に $R E$ と RG が導入され, 最後は RE,RG および $\mathrm{HB}$ が導 入される結果となっている.

以下, ケース Bの結果を分析すると, 既存機器に関 しては，更新年が遅くなるに従ってまず相対的に性能 の低い $\mathrm{RE}$ を撤去し, 次に $R G$ を撤去し, 最後に $\mathrm{BS}$ を撤去する結果となっている，新規導入機器としては まず REが導入され，次に既設 RG の撤去に伴いより 高性能な RGが導入され，最後に HP が導入される.

新規導入機器の容量に関しては, ケース A および $\mathrm{B}$ の場合とも更新年が遅くなるに伴って複雑な変化を している. ケース Aに関し， $\tau=7 \sim 12$ 年において $\mathrm{HB}$ の容量が增大し, 逆に RG の容量が減少するのは, $\mathrm{HB}$ の性能向上率が $\mathrm{RG}$ より高いためである。また， $\tau=15 \sim 21$ 年において性能向上率の高い $\mathrm{HB}$ の容量 は增大するが, 電力の基本料金低減化のため RE の容 量が減少し，RGの容量が增大する．ケース B に関し ても, 電力の基本料金低減化のため REの容量が減し, $\mathrm{RG}$ の容量が增大する結果となっている。.ただし，ケー ス Bのように蓄熱槽 IHB が無いと，各更新年に対す るこれらの最適機器容量の合計值はすべて一致してい る. ケース Bの $\tau=16 \sim 21$ 年において, $\mathrm{HP}=118 \mathrm{~kW}$ となっているのは，表 3 に示す下限制約に拘束された 結果である.

\subsection{2 技術進歩による機器性能向上率の影響分析}

技術進歩に伴って将来の機器性能向上率がより高く 見込まれる場合, 年間総経費削減率がより高くなると 予想されるのは自然である。図7には，逆にケースA からケース A-1 〜A-3 の上うに性能向上率が低滅する に従って, 年間総経費削減率が低下する結果が明示さ れている. 図 7 は, また, 性能向上率の低減に伴って 最適更新年が早くなる結果を示している。これは，性 能向上率が高い場合，早急に更新するのではなく，あ る程度機器類の性能が向上した段階で更新を行う方が 有利であるためと考えられる。

更新年 $\tau$ の変化に対する更新システムの機器構成
Table 6 Optimal capacity of equipment of renewal system

\begin{tabular}{|c|c|c|c|c|c|c|c|c|c|}
\hline \multirow{3}{*}{\multicolumn{2}{|c|}{$\begin{array}{c}\text { Renewal } \\
\text { year } \\
\tau \mathrm{y}\end{array}$}} & \multicolumn{8}{|c|}{ Capacity of equipment $\mathrm{kW}$} \\
\hline & & \multicolumn{3}{|c|}{ Existing equipment } & \multicolumn{5}{|c|}{ Newly installed equipment } \\
\hline & & $\mathrm{RE}$ & $\mathrm{BS}$ & RG & $\mathrm{RE}$ & BS & RG & HP & $\mathrm{HB}$ \\
\hline & $<7$ & 694 & 113 & 1389 & - & - & - & - & - \\
\hline \multirow{15}{*}{$\begin{array}{l}\varangle \\
\vdots \\
y \\
u \\
J\end{array}$} & 7 & dis. & 113 & dis. & - & - & 1583 & - & 264 \\
\hline & 8 & dis. & 113 & dis. & - & - & 1581 & - & 265 \\
\hline & 9 & dis. & 113 & dis. & - & - & 1580 & - & 265 \\
\hline & 10 & dis. & 113 & dis. & - & - & 1578 & - & 266 \\
\hline & 11 & dis. & 113 & dis. & - & - & 1577 & - & 267 \\
\hline & 12 & dis. & 113 & dis. & - & - & 1575 & - & 268 \\
\hline & 13 & dis. & 113 & dis. & 990 & - & 1093 & - & - \\
\hline & 14 & dis. & 113 & dis. & 972 & - & 1111 & - & - \\
\hline & 15 & dis. & 113 & dis. & 978 & - & 604 & - & 270 \\
\hline & 16 & dis. & 113 & dis. & 969 & - & 612 & - & 271 \\
\hline & 17 & dis. & 113 & dis. & 961 & - & 619 & - & 271 \\
\hline & 18 & dis. & 113 & dis. & 952 & - & 627 & - & 272 \\
\hline & 19 & dis. & 113 & dis. & 944 & - & 634 & - & 273 \\
\hline & 20 & dis. & 113 & dis. & 935 & - & 642 & - & 274 \\
\hline & 21 & dis. & 113 & dis. & 927 & - & 650 & - & 274 \\
\hline \multirow{15}{*}{$\begin{array}{l}\infty \\
\tilde{u} \\
\tilde{u} \\
\tilde{J}\end{array}$} & 7 & dis. & 113 & 1389 & 694 & - & - & - & \\
\hline & 8 & dis. & 113 & 1389 & 694 & - & - & - & \\
\hline & 9 & dis. & 113 & 1389 & 694 & - & - & - & \\
\hline & 10 & dis. & 113 & 1389 & 694 & - & - & - & \\
\hline & 11 & dis. & 113 & dis. & 1025 & - & 1058 & - & \\
\hline & 12 & dis. & 113 & dis. & 1007 & - & 1076 & - & \\
\hline & 13 & dis. & 113 & dis. & 990 & - & 1093 & - & \\
\hline & 14 & dis. & 113 & dis. & 972 & - & 1111 & - & \\
\hline & 15 & dis. & 113 & dis. & 955 & - & 1128 & - & \\
\hline & 16 & dis. & dis. & dis. & 1011 & - & 954 & 118 & \\
\hline & 17 & dis. & dis. & dis. & 997 & - & 968 & 118 & \\
\hline & 18 & dis. & dis. & dis. & 982 & - & 983 & 118 & \\
\hline & 19 & dis. & dis. & dis. & 968 & - & 997 & 118 & \\
\hline & 20 & dis. & dis. & dis. & 954 & - & 1011 & 118 & \\
\hline & 21 & dis. & dis. & dis. & 940 & - & 1025 & 118 & \\
\hline
\end{tabular}

*dis. $=$ discarded

を示した図 8 は, すべてのケースにおいて既設機器の RE およびRG は撤去するが, 機器性能向上率が小さ いBS は存続させる結果となっている。.また, 機器性 能向上率がケース A と比較して相対的に低いケース A-1 A-3 に関しては, すべて新規導入機器機種とし て RGおよびHBが採用されている。ささらに，ケース A およびケース A-1 A-3 に対するそれぞれの最適更 新年 $\tau^{*}$ における機器構成はすべて同一の結果となっ ている. 


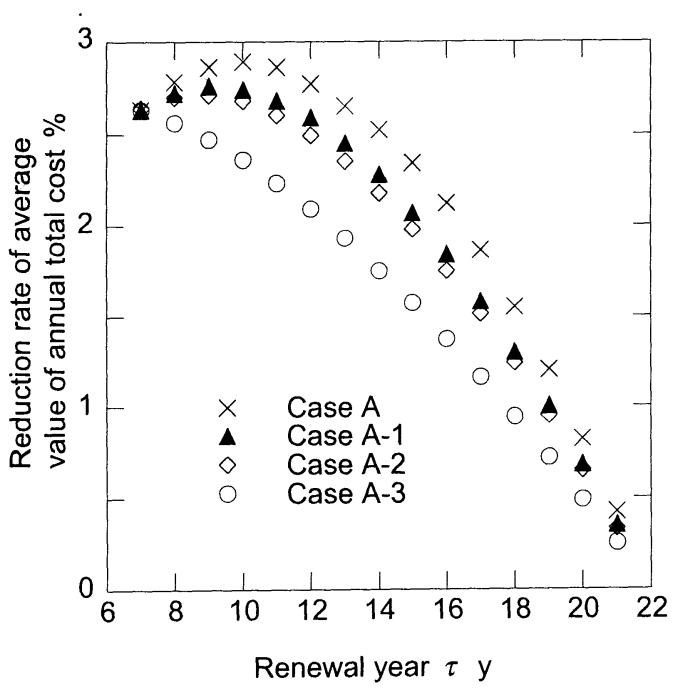

Fig. 7 Reduction rate of average value of annual total cost (influence of upgrading rate of performance)

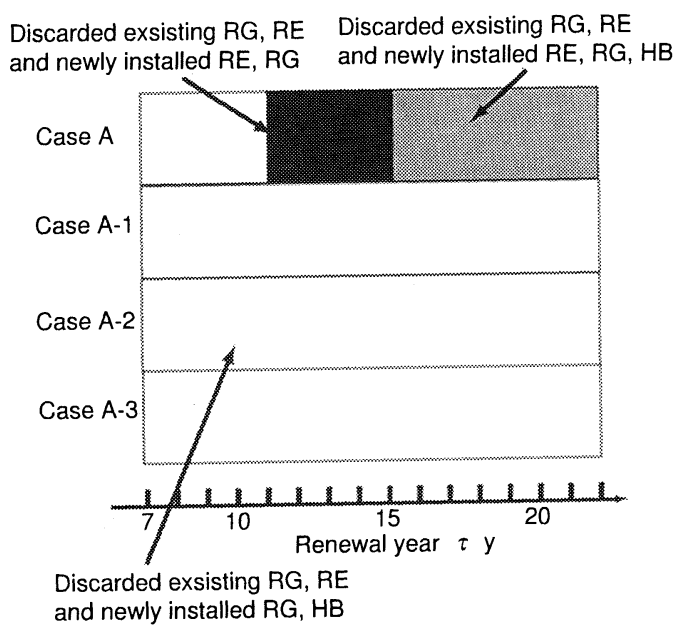

Fig. 8 Diagram of discarded and newly installed equipment of renewal system

\section{4. 結 言}

本報では，エネルギー供給システムの更新計画を合 理的に立案するための最適化手法を提案し, 事務所ビ ルに対する数值計算を通じてその有効性を検証した。 新設のシステム計画と比較して, 考慮すべき要因が非 常に多い更新計画問題に対して, シミュレーション手
法と異なる数理計画手法を導入し, 最適解を導出でき ることが判明した，すなわち，本手法により，設定し た目的関数に対して既設機器のどの機器を撤去し，ま た新規にどの機器を導入して更新を行えばよいかを， 導入機器類の最適機器容量を含めて決定できることが 判った。 得られた主要結果を以下に示す。

（イ）システムの更新をあまり早期に行い過ぎると, 技術進歩を反映した高効率機器類の導入ができず, 経 済的に得策ではない. 一方, 更新時期をあまり遅らせ れば，低効率な既存機器を長く使う結果となり，年間 総経費削減率も低くなる。

（口）高性能な新規導入可能機器が出現した場合, 新旧の機器更新がより早期に行われ，年間総経費削減 率も高くなる。

（ハ）各種機器の性能向上率が将来高く予想される に従ってシステム全体の年間総経費削減率は向上する。 ただし，そのためには更新を適切に遅らせて実施する ことが必要である。

今回の検討においては, 既存機器類の劣化について は無視したが, この特性の影響や, システムの機器余 裕率ならびに省エネルギー性, 環境性, さらに他の対 象ビルなどに対する検討については今後の研究課題と したい.

\section{文献}

(1) Ito, K. and Yokoyama, R, Optimal Planning of Cogeneration Systems (in Japanese), (1990), SangyoTosho.

(2) Yokoyama, R., Ito, K. and Matsumoto, Y., Optimal Multistage Expansion Planning of a Gas Turbine Cogeneration Plant, Trans. ASME, J. Eng. Gas Turbines Power, 118-4 (1996), 803-809.

(3) Gamou, S., Ito, K., Yokoyama, R. and Yoshida, S., Structural Optimization of an Energy Supply System from Economic Viewpoint, JSME International Journal, Series $B, 47-2$ (2004), 173-179.

(4) Yokoyama, R. and Ito, K., A Novel Decomposition Method for MILP and Its Application to Optimal Operation of a Thermal Storage System (in Japanese), Trans. JSME, Series C, 65-638, (1999), 4164-4171

(5) Brooke, A., et al., GAMS Release 2.50 a User's Guide, (1998), GAMS Development Corp.

(6) The Society of Heating, Air-Conditioning and Sanitary Engineers of Japan (ed.), Planning, Design and Evaluation of Cogeneration Systems by City Gas (in Japanese), The Society of Heating, Air-Conditioning and Sanitary Engineers of Japan, (1995).

(7) Research Institute for Buildings Construction Prices (ed.), Buildings Construction Prices (in Japanese), 948 (20023), Research Institute for Buildings Construction Prices. 